\title{
ANALISIS KESALAHAN BERBAHASA DALAM ARTIKEL ILMIAH DOSEN STAIN GAJAH PUTIH TAKENGON
}

\author{
Putri Wulan Dhari \\ IAIN Takengon, Aceh Tengah, Aceh \\ Email: putriwulandhari89@gmail.com
}

\begin{abstract}
This study aims to described an language error in scientific article made by lecturer in STAIN Gajah Putih Takengon. The data of this research were taken from four scientific article made by lecturer in STAIN Gajah Putih Takengon. Research data in the form of errors in Indonesian language in spelling, diction, sentences, and paragraphs contained in a scientific article. Data collection techniques in the form of documentary study technique. The research results show that; 1) 753 data errors were found in the total; 2) the most common language errors is in spelling, which is 463 data, 3) errors in diction which is 215 data; 4) errors in the use of sentences of 67 data; and 5) errors in the paragraph aspects were found in 8 data.
\end{abstract}

Keywords: language errors, scientific article

\begin{abstract}
Abstrak: Penelitian ini bertujuan mendeskripsikan kesalahan berbahasa dalam artikel ilmiah dosen STAIN Gajah Putih Takengon. Sumber data penelitian ini adalah empat artikel ilmiah dosen STAIN Gajah Putih Takengon. Data penelitian berupa kesalahan berbahasa Indonesia dalam ejaan, diksi, kalimat, dan paragraf yang terdapat dalam artikel ilmiah. Teknik pengumpulan data berupa teknik studi dokumenter. Hasil penelitian menunjukkan bahwa; 1) ditemukan kesalahan berbahasa sebanyak 753 data secara keseluruhan; 2) kesalahan berbahasa yang paling banyak ditemukan adalah kesalahan pada ejaan, yaitu sebanyak 463 data; 3) kesalahan dalam pemilihan kata (diksi), yaitu sebanyak 215 data; 4) kesalahan dalam pemakaian kalimat sebanyak 67 data; dan 5) kesalahan pada aspek pemaragrafan ditemukan sebanyak 8 data.
\end{abstract}

Kata kunci: kesalahan berbahasa, artikel ilmiah

\section{PENDAHULUAN}

Tugas utama seorang dosen adalah menjalankan Tri Dharma Perguruan Tinggi, yaitu pengajaran, penelitian dan pengabdian masyarakat. Berdasarkan pernyatan tersebut, maka kegiatan meneliti bagi seorang dosen adalah sebuah keharusan. Berbicara mengenai penelitian tentu erat kaitannya dengan keterampilan menulis. Bahasa sebagai media dalam mengungkap ide atau gagasan dalam ragam tulis menjadi faktor utama untuk menyosialisasikan dan menyebarkan hasil penelitian. Dengan demikian, keterampilan 
menulis seorang dosen harus terus-menerus ditingkatkan agar kualitas tulisan ilmiahnya semakin baik.

Namun, hakikat yang dijumpai pada era ini temuan kesalahan-kesalahan pemakaian bahasa dalam artikel ilmiah dosen masih banyak jumlahnya. Penelitian yang dilakukan oleh Hazma dan Wastu (2017:80) menunjukkan dua hal. Pertama, terdapat kelemahan dalam berbahasa dalam artikel-artikel ilmiah di jurnal-jurnal Polban yang meliputi kesalahan dalam pemakaian EBI/EYD, penulisan kata, kesalahan penulisan kalimat, pemakaian kosakata yang tidak tepat dan tidak baku, serta ketidakpaduan paragraf. Kedua, aspek kebahasaan ternyata belum menjadi perhatian serius dan belum disikapi dengan benar oleh penulis artikel di Polban karena belum ditaatinya pedoman penulisan artikel. Selain itu, Ghufron dalam penelitiannya mengungkapkan hal yang kurang lebih sama dengan Hazma dan Wastu. Penelitian yang dilakukan Ghufron (2014:9) mengungkapkan bahwa kesalahan penulisan artikel ilmiah pada jurnal ilmiah Humanis, Humanitas, Penabastra, dan Edu-Kata dibedakan atas kesalahan anatomi dan kesalahan bahasa. Kesalahan dalam penggunaan bahasa didapati pada kesalahan dalam kodifikasi paragraf, kodifikasi kalimat, diksi, dan penggunaan ejaan.

Sejalan dengan penelitian Ghufron, penelitian Sultan (2013:37) juga menunjukkan bahwa terdapat 58 kalimat $(20,94 \%)$ tergolong tidak efektif dalam artikel penelitian tahun 2011 yang diarsipkan oleh Lembaga Penelitian Universitas Negeri Makassar. Penelitian itu menjabarkan ketidakefektifan kalimat yang terjadi disebabkan delapan hal, yaitu ketidaklogisan, kerancuan, pemborosan, ketidaklengkapan unsur, kesalahan pasif, penonjolan persona, ketidaksatuan gagasan, dan ketidakparalelan. Bukan hanya itu, penelitian Azmi dan Rajab menyimpulkan bahwa terdapat dua jenis kesalahan berbahasa pada artikel jurnal di lingkungan Universitas Syiah Kuala, yaitu kohesi dan koherensi (2018:159).

Pada dasarnya, kualitas artikel yang baik dipengaruhi oleh tiga hal, yaitu isi, sistematika, dan bahasa (Basuki dalam Sultan, 2013:33). Berdasarkan pernyataan tersebut, bahasa menjadi salah satu tolok ukur penting dalam menentukan berkualitas atau tidaknya artikel ilmiah seorang penulis. Maka dari itu, kemampuan berbahasa secara baik dan benar menjadi keniscayaan dalam kegiatan ilmiah karena bahasa adalah peranti komunikasi ilmiah utama (Suriasumantri dalam Hazma dan Wastu, 2017:68).

Studi awal telah dilakukan terhadap artikel ilmiah yang dihasilkan oleh dosen STAIN Gajah Putih Takengon. Hasilnya menunjukkan bahwa terdapat kesalahan 
pemakaian bahasa dalam artikel tersebut. Hal ini tentu akan berdampak pada pembaca karena dipublikasikannya sebuah artikel ilmiah agar ilmu dan pengetahuan yang ada di dalamnya bisa digunakan untuk kemaslahatan pembaca. Namun, artikel yang memiliki kualitas bahasa yang kurang baik tentu berdampak pada pemahaman pembaca. Oleh karena itu, tujuan penelitian ini untuk mendeskripsikan kesalahan berbahasa dalam artikel ilmiah dosen STAIN Gajah Putih Takengon. Hasil penelitian ini diharapkan dapat membantu para dosen dan mahasiswa agar tidak melakukan kesalahan-kesalahan berbahasa, terutama kesalahan-kesalahan yang sama dalam tulisan ilmiah.

Kesalahan berbahasa adalah terjadinya pembelokan aturan dalam kegiatan berbahasa, baik secara lisan maupun tertulis (Suwandi, 2010:165). Pembelokan/ penyimpangan itu dikategorikan menjadi kesalahan (error) dan kekeliruan (mistake). Kesalahan berbahasa adalah pemakaian bahasa di luar aturan yang berlaku dalam bahasa itu. Dalam pada itu, kekeliruan dapat pula dikatakan sebagai pemakaian bahasa di luar aturan yang berlaku dalam berbahasa, tetapi tidak dianggap sebagai sebuah pelanggaran berbahasa (Ramaniyar, 2017:71). Kekeliruan berbahasa dapat terjadi mungkin disebabkan oleh tekanan emosional, kelelahan, ingatan yang terbatas, dsb., sedangkan kesalahan berbahasa terjadi salah satunya karena perbedaan penguasaan kaidah-kaidah gramatikal (grammatical competence) antara seseorang dengan seseorang yang lain.

Mengacu pada penjelasan di atas, analisis kesalahan berbahasa adalah studi yang berkaitan dengan kesalahan berbahasa yang digunakan oleh seseorang dalam berkomunikasi, mengelompokkan kesalahan tersebut, menjelaskan penyebabnya, dan memperbaiki kesalahan sesuai kaidah kebahasaan yang berlaku. Dalam menganalisis kesalahan berbahasa, model kerangka analisis yang digunakan adalah model kerangka pengembang yang dibuat oleh Suwandi (2010:169) yang meliputi: 1) ejaan, 2) diksi, 3) kalimat, dan 4) paragraf.

\section{LANDASAN TEORI}

Ada empat model kerangka yang digunakan dalam menganalisis kesalahan berbahasa dalam penelitian ini, yaitu ejaan, diksi, kalimat, dan paragraf. Keempat tipe analisis di atas adalah satu kesatuan yang saling melengkapi antara satu dan lainnya. Kalimat yang baik dibangun oleh ejaan dan pemilihan kata yang baik pula. Begitu pula dengan paragraf. Paragraf dikatakan memenuhi syarat jika kalimat-kalimat yang digunakan di dalamnya saling bersinergi membentuk kesatuan dan kesinambungan ide. 
Dengan demikian, kolaborasi antara ejaan, diksi, kalimat, dan paragraf menjadi hal yang sangat penting dalam mengkonstruksi sebuah tulisan yang baik dan benar. Selanjutnya, akan dibahas kerangka analisis tersebut satu persatu.

Ejaan merupakan ketentuan yang mengatur seseorang dalam mendeskripsikan bunyi bahasa dan menggunakan tanda baca dalam tulisan (KBBI dalam Tussolekha, 2019:36). Bunyi bahasa yang dimaksud dalam pernyataan di atas, meliputi pemakaian huruf dan penggunaan kata. Saat ini yang mengatur penggunaan bunyi bahasa dan tanda baca di Indonesia adalah PUEBI (Pedoman Umum Ejaan Bahasa Indonesia). Dalam PUEBI, bukan hanya pemakaian huruf dan penggunaan kata saja yamg dijabarkan, melainkan juga penggunaan tanda baca dan unsur serapan. Namun, dalam penelitian ini, ejaan yang dibahas hanyalah berupa pemakaian huruf kapital dan huruf miring, serta penggunaan kata dan tanda baca. Meskipun terkesan sederhana, penggunaan ejaan dan tanda baca tersebut adalah hal dasar yang menentukan apakah sebuah tulisan dapat dikatakan sebagai tulisan yang baik dan benar. Selain itu, ketika seorang penulis memperhatikan ejaan dalam tulisannya, itu artinya ia akan mempermudah pembaca dalam pemaknaan teks yang tepat.

Selanjutnya, diksi merupakan ketepatan seseorang dalam memilih kata saat berkomunikasi (dalam hal ini bahasa tulisan). Poin penting yang dibahas dalam diksi adalah kemahiran dalam menyeleksi bentuk kata yang tidak hanya selaras dengan situasi dan kondisi yang ada, tetapi juga dengan nilai rasa pembaca/pendengar (Sasangka, 2013:97). Sama halnya dengan ejaan, penggunaan diksi yang tepat akan membantu pembaca dalam pemaknaan teks yang tepat. Pembaca lebih mudah dan cermat dalam membedakan makna kata karena melalui diksi mereka akan lebih berhati-hati dengan adanya pergeseran makna (Sasangka, 2013:97). Selain itu, menggunakan diksi yang selaras akan membuat sebuah tulisan menjadi lebih menarik dan tidak monoton sehingga selain lebih mudah dalam memahami tulisan, pembaca akan terhindar dari rasa bosan dan jenuh. Ruang lingkup diksi dalam penelitian ini berupa penggunaan kata berimbuhan, pemilihan konjungsi, dan penggunaan kata tidak baku.

Hal berikutnya yang menjadi kajian penelitian ini adalah kalimat. Keberadaan kalimat adalah hal yang penting dalam menentukan keberhasilan komunikasi. Khususnya dalam bahasa tulisan, kalimat yang baik dan benar akan memudahkan pembaca dalam memahami pikiran-pikiran penulis. Apalagi, hanya kalimatlah sarana komunikasi satusatunya antara penulis dan pembaca dalam bahasa tulisan. Oleh karena itu, perlu adanya 
kalimat yang efektif untuk merepresentasikan pemikiran penulis dengan tepat. Kalimat efektif adalah kalimat yang mampu mengungkapkan pikiran/ide penulis secara sederhana, tetapi tetap mewujudkan kesepahaman pikiran/ide dengan pembacanya (Sasangka, 2013:187). Selanjutnya, sesuai dengan pernyataan Arifin dan Amran (2010:97), analisis kalimat efektif dalam penelitian ini meliputi, kesepadanan, keparalelan, kepaduan, kehematan, kecermatan, ketegasan, dan kelogisan.

Model kerangka analisis terakhir dalam penelitian ini, yaitu paragraf. Secara sederhana, paragraf adalah gabungan beberapa kalimat yang membentuk kesatuan ide/gagasan. Paragraf dikatakan baik jika diproyeksikan dengan jelas, tidak bertele-tele, berkaitan, dan menunjukkan satu kesatuan makna antarkalimatnya. Paragraf seperti inilah yang akan berfaedah bagi pembaca dalam memahami tulisan, juga benefit lainnya, yaitu efisiensi waktu dalam membacanya. Ada dua syarat sebuah paragraf dianggap sebagai paragraf yang baik, yaitu kohesi dan koherensi (Azmi dan Rajab, 2018:152). Kohesi adalah kesatuan ide dalam sebuah paragraf. Di sisi lain, koherensi, yaitu adanya kesinambungan antarkalimat dalam paragraf tersebut.

\section{METODE PENELITIAN}

Metode yang digunakan dalam penelitian ini adalah metode kualitatif deskriptif. Sumber data penelitian ini adalah empat artikel ilmiah dosen STAIN Gajah Putih Takengon. Data penelitian berupa kesalahan berbahasa Indonesia dalam ejaan, diksi, kalimat, dan paragraf yang terdapat dalam artikel ilmiah. Lebih lanjut lagi, teknik pengumpulan data berupa teknik studi dokumenter. Penelitian ini juga menggunakan triangulasi sumber sebagai teknik validitas data. Analisis data yang digunakan berpedoman pada Miles dan Huberman (dalam Rochmadi dan Yakub, 2017:36) yang meliputi empat tahapan, yaitu: (1) pengumpulan data, (2) reduksi data, (3) penyajian data, dan (4) penarikan simpulan.

\section{HASIL DAN PEMBAHASAN}

Ragam kesalahan berbahasa yang dideskripsikan dalam tulisan ini didasarkan pada hasil analisis yang ditemukan dalam artikel ilmiah dosen STAIN Gajah Putih Takengon. Mengingat kesalahan pemakaian bahasa yang ditemukan dalam penelitian ini tergolong banyak, maka hanya beberapa kesalahan saja yang akan dibahas dalam tulisan ini. 


\section{Ejaan dan Tanda Baca}

Berdasarkan hasil penelitian, terdapat 463 kesalahan yang ditemukan berkaitan dengan pemakaian ejaan dan tanda baca. Pemakaian ejaan yang ditemukan meliputi kesalahan dalam pemakaian huruf kapital dan huruf miring, penggunaan tanda baca, serta penulisan kata, seperti penulisan gabungan kata, preposisi, dan partikel.

\section{a. Pemakaian huruf kapital}

Perhatikan contoh berikut ini.

(1) Sementara itu yang menjadi informan terkait data tentang peran dan

FKUB Aceh Tengah dalam hal adalah kepala kantor kementerian agama Aceh Tengah dan kepala forum kerukunan umat beragama Aceh Tengah. (D353-354.AI2, 2019:55)

Berdasarkan contoh dia atas, terdapat kesalahan pada pengunaan huruf kapital dalam frasa berhuruf tebal. Huruf kapital salah satunya digunakan sebagai "huruf pertama unsur nama jabatan dan pangkat yang dipakai sebagai pengganti nama orang tertentu, nama instansi, atau nama tempat" (PUEBI, 2016:8). Dengan kata lain, meskipun pada nama jabatan pada contoh di atas tidak diikuti nama orang, tentu tetaplah menunjuk pada orang tertentu sehingga tetap memakai huruf kapital di setiap huruf pertama unsur nama jabatan. Berdasarkan penjelasan di atas, penulisan yang benar dapat ditulis "Kepala Kementerian Agama Aceh Tengah dan $\boldsymbol{K}$ epala $\boldsymbol{F}$ orum Kerukunan $\boldsymbol{U}$ mat $\boldsymbol{B}$ eragama Aceh Tengah".

\section{b. Pemakaian huruf miring}

Pada bagian ini, kesalahan yang paling banyak terjadi adalah tidak menggunakan huruf miring pada kata atau ungkapan dalam bahasa asing. Contoh kesalahan yang ditemukan ada pada artikel Nasution dan Awal (2019:65), yang menyebut kata/ungkapan asing "peer de briefing", yang seharusnya ditulis "peer de briefing” (D86.AI1, 2019:65).

\section{c. Pemakaian tanda koma}

Kesalahan dalam pemakaian tanda koma yang paling banyak ditemukan adalah tidak menggunakan tanda koma ketika memerinci sesuatu. Padahal, tanda koma juga digunakan sebelum konjungsi yang mengakhiri pemerincian, seperti yang ditemukan pada artikel Sayska dan Muhammad (2019:24) yang menyebutkan penggalan kalimat “... homoseksual, heteroseksual, biseksual maupun aseksual” dapat diperbaiki menjadi “... homoseksual, heteroseksual, biseksual, maupun aseksual”'(D615.AI4, 2019:24). 


\section{d. Penulisan gabungan kata}

Ada banyak kata dalam bahasa Indonesia yang merupakan bentuk terikat dan tidak dapat berdiri sendiri sehingga akan bergabung penulisannya jika dipadukan dengan kata lain. Contohnya dapat ditemukan dalam artikel Riza (2019:48) pada kata "antar umat" yang seharusnya ditulis "antarumat" (456-460.AI2, 2019:60). Hal ini juga ditemukan dalam artikel Riza (2019:53) pada kata "sang maha kuasa" yang seharusnya ditulis. "Sang Mahakuasa" (D751.AI2, 2019:53). Ada banyak bentuk terikat lain yang penulisannya sama seperti non-, pra-, pasca-, adi-, multi-, serba-, anti-, dan lain-lain.

\section{e. Preposisi dan Partikel}

Masih berkaitan dengan ejaan, kesalahan lain yang ditemukan dalam penelitian ini berupa preposisi dan partikel. Contoh kesalahan tersebut dapat dilihat melalui contoh kata "kedalam" (D518.AI3, 2019:39) dalam artikel Umar dan Nurul (2019:39), “diperguruan tinggi”" (D578.AI3, 2019:46) dalam artikel Umar dan Nurul (2019:46), "bidadari lah" (D702.AI4, 2019:29) dalam artikel Sayska dan Muhammad (2019:29), dan "manusiapun" (D720.AI4, 2019:32) dalam artikel Sayska dan Muhammad (2019:32).

Tentu haruslah dibedakan penggunaan di-/ke- sebagai prefiks dan di-/ke- sebagai preposisi. Pada kata "digunakan" misalnya, penulisannya memang harus digabungkan karena di- di sini memang berfungsi sebagai imbuhan. Sebaliknya, di-/ke- yang biasanya diikuti oleh kata tempat harus ditulis terpisah. Berbeda halnya dengan preposisi, penulisan partikel seperti -kah, dan -lah, harus digabungkan dengan kata sebelumnya, kecuali penulisan partikel -pun. Pada dasarnya partikel -pun ditulis terpisah dari kata sebelumnya. Namun, partikel -pun yang merupakan unsur kata penghubung harus ditulis serangkai, seperti ataupun, biarpun, bagaimanapun, maupun, meskipun, walaupun, dan sebagainya. Dengan demikian, penulisan yang benar contoh kalimat di atas adalah "ke dalam", “di perguruan tinggi”, "bidadarilah" (D702.AI4, 2019:29), dan "manusia pun".

\section{Diksi (Pemilihan Kata)}

Berdasarkan hasil penelitian, terdapat 215 kesalahan yang ditemukan berkaitan dengan diksi. Ketidaktepatan pemakaian diksi yang ditemukan meliputi penggunaan kosa kata yang kurang tepat, imbuhan yang tidak tepat, pemilihan konjungsi, dan penggunaan kata tidak baku. 


\section{a. Penggunaan imbuhan}

Kesalahan yang terjadi dalam hal ini, misalnya sering melesapkan afiks pada sebuah kata kerja. Perhatikan contoh-contoh berikut yang di ambil dari artikel Umar dan Nurul (2019:37) pada kalimat (2), serta Sayska dan Muhammad (2019:26) pada kalimat (3) berikut.

(2) Hasil PISA terbaru tahun 2015 memang mengalami peningkat seperti pada bidang matematika ... (D482.AI3, 2019:37)

(3) Setiap orang punya kecendrungan masing-masing. (D666.AI4, 2019:26)

Dalam bahasa Indonesia, jenis kata dapat berubah menjadi jenis lain jika dibubuhkan afiks pada bentuk dasarnya (Sasangka, 2013:64). Dalam bahasa lisan, ada beberapa afiks atau imbuhan yang sering dilesap oleh pembicara, seperti prefiks ber- dan meng-. Kebiasan dalam melesapkan afiks dalam bahasa lisan menjadikan penggunaan afiks dalam bahasa tulis menjadi kabur fungsinya. Hal ini terlihat pada contoh kalimat (1) dan (2) sehingga kata "peningkat" dapat ditulis "peningkatan" dan kata "punya" ditulis "mempunyai". Selain itu, dalam artikel Riza (2019:51) terdapat imbuhan yang tidak tepat penulisannya, yaitu dalam kata "di antisipasi" yang seharusnya ditulis “diantisipasi”" (D288.AI2, 2019:51). Kesalahan terjadi karena penulisan prefiks di- yang seharusnya ditulis serangkai, tetapi ditulis terpisah dengan kata yang mengikutinya.

\section{b. Konjugsi}

Ketidaktepatan konjungsi dapat dilihat melalui contoh berikut yang diambil dari artikel Nasution dan Awal (2019:73) pada kalimat (4), Umar dan Nurul (2019:43) pada kalimat (5), serta Sayska dan Muhammad (2019:25) pada kalimat (6).

(4) Pada masyarakat Gayo, secara budaya tidak terlalu mengedepankan usia, namun lebih kepada pada tutur keluarga. (D184.AI1, 2019:73)

(5) Jika dikategorikan kedalam tingkatan kreatif maka rata-rata ini berada pada level kurang kreatif. (D549.AI3, 2019:43)

(6) ... sama-sama memiliki kesenangan (baik secara psikis ataupun biologis) dan orientasi seksual bukan saja dengan lawan jenis akan tetapi bisa juga dengan sesama jenis. (D627-628.AI4, 2019:25)

Hal pertama yang harus dipahami adalah konjungsi dapat dibedakan menjadi konjungsi intrakalimat (dan, tetapi, sedangkan, sehingga, dll.) dan antarkalimat (namun, sebaliknya, akan tetapi, selain itu dll.). Sesuai dengan namanya, konjungsi 
intrakalimat digunakan untuk menghubungkan dua unsur atau lebih dalam satu kalimat, sedangkan konjungsi antarkalimat digunakan untuk menghubungkan antara kalimat satu dan kalimat yang lain. Dengan demikian, konjungsi "namun” pada contoh kalimat (4) tidak tepat karena digunakan sebagai penghubung intrakalimat, seharusnya konjungsi tersebut dapat diganti kata "tetapi".

Kedua, dua konjungsi kalimat majemuk bertingkat, seperti “jika-maka” tidak boleh digunakan bersamaan dalam satu kalimat karena dapat membingungkan. Oleh karena itu, kalimat (5) masih tidak tepat sehingga dapat diperbaiki dengan menghilangkan konjungsi "maka". Ketiga, bahasa Indonesia memiliki padanan kata yang disebut ungkapan idiomatik. Ungkapan idiomatik adalah kekhasan susunan pada suatu bahasa yang tidak boleh dihilangkan salah satu unsurnya (Arifin dan Amran, 2010:53), misalnya, baik ... maupun, antara ... dan, bukan ... melainkan, dan tidak ... tetapi. Dengan demikian, (6) tidak benar penggunaan konjungsinya.

\section{c. Akhiran -ir dan pelesapan huruf}

Kesalahan lain dalam pemilihan kata dapat dilihat dalam artikel Nasution dan Awal (2019:64) pada penggunaan kata “mengorganisir" (D213.AI1, 2019:64) dan artikel Riza (2019:57) pada penggunaan kata "mentolerir" (D401.AI2, 2019:57). Padahal, dalam bahasa Indonesia berstandar, akhiran -ir dipadankan dengan -asi atau -isasi. Selanjutnya, kata dasar yang berawalan $/ k /, / t /, / s /$, dan $/ p /$ akan luluh jika mendapatkan awalan meng- atau peng- sehingga kata “mempercayai' (D301.AI2, 2019:52) dalam artikel Riza (2019:52) seharusnya diganti menjadi “memercayai”.

\section{Kalimat}

Berdasarkan hasil penelitian, terdapat 67 kesalahan yang ditemukan berkaitan dengan diksi. Kesalahan dalam penggunaan kalimat dijabarkan berdasarkan ciri kalimat efektif, yaitu kesepadanan, kepaduan, kehematan, dan ketegasan. Contoh-contoh kesalahan tersebut dapat dilihat sebagai berikut.

(7) Dalam kasus tertentu seperti nikah siri, yang hingga pada saat ini menjadi hal yang kontroversi di Indonesia. (D27.AI1, 2019:61)

(8) Meningkatkan kompetensi guru harus sudah dilakukan dibangku pendidikan calon guru. (D493.AI3, 2019:38)

Kesalahan penggunaan kalimat pada kalimat di atas terjadi karena tidak adanya kejelasan subjek. Kejelasan subjek pada kalimat di atas dapat diminimalisasi dengan menghindari penggunaan preposisi, misalnya dalam dan pada (Arifin dan Amran, 
2010:97). Dengan demikian, kata “dalam" pada kalimat (7) dalam artikel Nasution dan Awal (2019:61) di atas dapat dihilangkan. Selain itu, kejelasan subjek pada kalimat (8) dapat dilakukan dengan mengubah konfiks "me-kan" pada kata "meningkatkan". Dengan demikian, posisi predikat bisa berubah menjadi subjek sehingga kata “Meningkatkan" pada kalimat (8) dalam artikel Umar dan Nurul (2019:38) di atas dapat diganti menjadi "Peningkatan".

Contoh kalimat berikut adalah salah satu contoh kalimat yang tidak padu dan tidak hemat yang dikutip dari artikel Nasution dan Awal (2019:61) pada kalimat (9) dan Sayska dan Muhammad (2019:24) pada kalimat (10).

(9) Di Indonesia tradisi dalam memelihara nasab selain karena pengaruh ajaran Islam sendiri yang merupakan agama mayoritas penduduknya dalam hal ini juga terdapat dalam kearifan lokal (local wisdom) masyarakatnya yang terdiri dari suku-suku yang beragam. (D49.AI1, 2019:61)

(10) Hal ini disebabkan karena merekalah kaum yang pertama kali melakukan perbuatan ini. (D752.AI4, 2019:24)

Kalimat yang tidak padu pada kalimat (9) menyebabkan informasi yang disampaikan menjadi terpecah-pecah. Di sisi lain, kalimat (10) dapat diperbaiki dengan membuang kata yang memang tidak diperlukan sehingga kalimat itu menjadi lebih hemat. Dalam contoh kalimat (10), kita dapat membuang salah satu dari konjungsi karena memiliki sinonim sehingga "disebabkan karena" dapat diperbaiki menjadi “disebabkan oleh" atau "karena" saja agar kalimat tersebut menjadi lebih hemat. Selanjutnya, contoh perbaikan kalimat (9) di atas dapat dilihat sebagai berikut.:

(9) Di Indonesia selain karena pengaruh ajaran Islam sebagai agama mayoritas, tradisi memelihara nasab juga dipengaruhi oleh kearifan lokal (local wisdom) masyarakatnya yang bersuku-suku.

\section{Paragraf}

Berdasarkan hasil penelitian, terdapat 8 kesalahan yang ditemukan berkaitan dengan paragraf. Kesalahan dalam penggunaan paragraf dijabarkan berdasarkan syarat paragraf yang baik, yaitu kesatuan (kohesi) dan kepaduan (koherensi) (Arifin dan Amran, 2010: 116). Contoh kesalahan dalam kohesi paragraf dapat dilihat dalam artikel Nasution dan Awal (2019:61) berikut. 
(11) Persoalan nasab atau garis keturunan merupakanb hal yang penting bagi berbagai lapisan suku bangsa di dunia. Darei berbagai macam kasus yang terjadi pada manusia, menunjukkan bahwa betapa pentingnya menjaga nasab yang sehingga pemenuhan hak dan kewajiban orang tua terhadap seorang anak yang dalam hal ini mencakup hal-hal yang berkaitan dengan perwalian, hukum waris dan pernikahan dapat terpenuhi. (D752.AI1, 2019:61)

Paragraf di atas tidak menunjukkan adanya kohesi karena terdapat dua ide pokok dalam satu paragraf. Paragraf yang menunjukkan ciri kohesi adalah hanya terdapat satu ide pokok dalam paragraf tersebut. Paragraf yang ide pokokya lebih dari satu dianggap tidak mempunyai kesatuan gagasan. Paragraf seperti inilah yang dapat menimbulkan makna ambigu. (Azmi dan Rajab, 2018:152-153). Oleh karena itu, untuk memperbaikinya bisa dilakukan dengan hany a menampilkan satu ide pokok pada setiap paragraf sehingga paragraf di atas dapat dipecah menjadi dua paragraf seperti di bawah ini.

(11) Persoalan nasab atau garis keturunan merupakan hal yang penting bagi berbagai lapisan suku bangsa di dunia. Banyaknya kasus berkaitan dengan nasab yang telah terjadi menunjukkan betapa pentingnya bagi sebuah keluarga untuk menjaga nasabnya sehingga pemenuhan hak dan kewajiban orang tua terhadap seorang anak mencakup hal-hal yang berkaitan dengan perwalian, hukum waris, dan pernikahan - dapat terpenuhi.

Selanjutnya, ada beberapa paragraf yang ditemukan dalam artikel ilmiah dosen yang tidak menunjukkan koherensi. Paragraf yang memiliki koherensi (kepaduan) yang baik salah satunya dapat dilihat melalui pengait paragraf (konjungsi) yang digunakan (Arifin dan Amran, 2010:117). Secara umum, konjungsi yang digunakan dalam artikel dosen masih belum tepat sehingga harus diperbaiki agar membentuk paragraf yang koheren. Kesalahan konjungsi tersebut erat pula kaitannya dengan ketidakpahaman dosen dalam membedakan konjungsi intrakalimat dan konjungsi antarkalimat.

Berdasarkan hasil penelitian, kesalahan dalam pemakaian ejaan ditemukan paling banyak di antara kesalahan lainnya, yaitu 463 data. Dalam ejaan, selain penggunaan tanda baca, kesalahan dalam pemakaian preposisi juga banyak ditemukan dalam penelitian ini. Hal ini menunjukkan masih ada dosen yang tidak dapat membedakan antara preposisi dan 
afiks. Hasil yang diperoleh ini sejalan dengan hasil penelitian Harjono (2018:265) yang menjelaskan bahwa mahasiswa masih rentan pemahamannya dalam membedakan preposisi "di" dan prefiks "di-“. Kata yang berhubungan dengan kolaborasi preposisi dan kata tempat, seperti di samping, di dalam, di atas, ke dalam dsb. seringkali ditulis serangkai. Padahal, penulisan di sebagai preposisi harus ditulis terpisah. Sebaliknya, terdapat pemisahan penulisan di- pada kata-kata disusun, didukung, digabung, didata dsb. yang seharusnya ditulis serangkai dengan kata di depannya.

Selain kesalahan ejaan, kesalahan yang umum ditemukan dalam artikel ilmiah dosen STAIN Gajah Putih adalah kata tidak baku. Berkaitan dengan penulisan kata tidak baku Martiningsih (2013:80) dalam penelitiannya juga menyebutkan banyak penulisan kata yang tidak baku yang ditemukan pada mahasiswa, seperti “ketrampilan" sepatutnya ditulis “keterampilan"; "praktek" sepatutnya "praktik"; dan "apotik" sepatutnya “apotek”. Selain itu, hal serupa dijelaskan dalam penelitian Ghufron (2014:8) yang menemukan diksi yang tidak cermat. Ketidakcermatan diksi tersebut berupa ketidakcermatan dalam konsep/makna kata, bentuk kata, ragam kata, dan kata tugas.

Selanjutnya, kesalahan dalam penggunaan kalimat ditemukan sebanyak 66 data. Berdasarkan hasil penelitian ini, artikel ilmiah dosen STAIN Gajah Putih masih ditemukan kalimat yang tidak efektif. Hasil ini sejalan dengan penelitian Sultan (2013:37) yang dalam hasil penelitiannya menunjukkan bahwa terdapat 58 kalimat $(20,94$ $\%$ ) yang tergolong tidak efektif. Beliau juga menambahkan penemuan ini adalah masalah yang penting karena penulisan karya ilmiah memiliki tujuan yang penting dalam mengemukakan gagasan dan menyebarluaskan ilmu pengetahuan.

Terakhir sehubungan dengan paragraf ditemukan kesalahan penulisan paragraf sebanyak 8 data. Berdasarkan hasil tersebut dapat diasumsikan bahwa paragraf yang dibentuk dalam artikel ilmiah STAIN Gajah Putih masih belum memenuhi syarat penulisan paragraf yang baik. Dalam hal kepaduan (koherensi) paragraf misalnya, ada beberapa paragraf yang ditemukan tidak menggunakan konjungsi yang tepat. Hal ini sesuai dengan penelitian Azmi dan Rajab (2018:158) yang menunjukkan kesalahan pada konjungsi terjadi pada dua jenis konjungsi, yaitu (1) konjungsi intrakalimat (dan, serta, jika, maka, namun, tetapi, apabila, sedangkan, agar, meskipun, setelah, seandainya, dan karena; dan (2) konjungsi antarkalimat (dengan demikian, namun, dan karenanya). 


\section{KESIMPULAN}

Berdasarkan hasil penelitian, disimpulkan bahwa dalam artikel ilmiah dosen STAIN Gajah Putih; 1) ditemukan kesalahan berbahasa sebanyak 753 data secara keseluruhan; 2) kesalahan berbahasa yang paling banyak ditemukan adalah kesalahan pada ejaan, yaitu sebanyak 463 data; 3) kesalahan dalam pemilihan kata (diksi), yaitu sebanyak 215 data; 4) ada 67 data kesalahan penggunaan kalimat yang ditemukan sehingga menyebabkan kalimat-kalimat tersebut menjadi tidak efektif; dan 5) kesalahan pada aspek pemaragrafan ditemukan sebanyak 8 data yang meliputi kohesi dan koherensi.

\section{DAFTAR PUSTAKA}

Azmi, Nurul dan Rajab Bahry. (2018). Analisis Kesalahan Berbahasa dalam Artikel Jurnal di Lingkungan Universitas Syiah Kuala. Master Bahasa (Online), 6(2), 149-160.

http://jurnal.unsyiah.ac.id/MB/article/view/11659

Arifin, E. Zaenal dan S. Amran Tasai. (2010). Cermat Berbahasa Indonesia untuk Perguruan Tinggi. Jakarta: Akademika Pressindo.

Badan Pengembangan dan Pembinaan Bahasa. (2016). Pedoman Umum Ejaan Bahasa Indonesia. Jakarta: Kementerian Pendidikan dan Kebudayaan.

Ghufron, Syamsul. (2014). Artikel Ilmiah: Anatomi, Bahasa, dan Kesalahannya. EduKata (Online), 1(1), 1-10.

http://e-jurnal.unisda.ac.id/index.php/kata/ article/view/152/41

Harjono, Nyoto. (2018). Kelaziman Kesalahan Berbahasa dalam Menulis Laporan Penelitian. Scholaria: Jurnal Pendidikan dan Kebudayaan (Online), 8(3), 264-272. http://download.garuda.ristekdikti.go.id/article.php?article= 786015\&val=10281\&title=Kelaziman\%20Kesalahan\%20Berbahasa\%20dalam\%20 Menulis\%20Laporan\%20Penelitian

Hazma dan Wastu Kurning P. (2017). Peran Bahasa Indonesia dalam Meningkatkan Kualitas Jurnal di Polban. Sigma-Mu (Online), 9(1), 66-81.

https://jurnal.polban.ac.id/index.php/sigmamu/article/download/969/803

Mulyana. (2005). Kajian Wacana: Teori, Metode, dan Aplikasi Prinsip-Prinsip Analisis Wacana. Yogyakarta: Tiara Wacana.

Martiningsih. (2013). Kesalahan Berbahasa Indonesia Mahasiswa S-1 PGSD STIKIP Nuuwar Fak-Fak. Jurnal Penelitian Ilmu Pendidikan (Online), 6(1), 74-82.

https://media.neliti.com/media/publications/122960-ID-kesalahan-berbahasaindonesia-mahasiswa.pdf

Nasution, Mustafa Kamal dan Awal Kurnia Putera Nasution. (2019). Sistem Kekerabatan Masyarakat Gayo dan Relevansinya dengan Ajaran Islam. Jurnal As-Salam (Online), 3(1), 23-35. 
http://jurnal-assalam.org/index.php/JAS/article/view/120

Ramaniyar, Eti. (2017). Analisis Kesalahan Berbahasa Indonesia Pada Penelitian Mini Mahasiswa. Jurnal Edukasi (Online), 15(1), 70-80.

journal.ikippgriptk. ac.id/index.php/edukasi/article/download/407/389

Riza, Muhammad. (2019). Relasi Antar Iman di Negeri Syari’at Islam (Studi Peran dan Fungsi FKUB dalam Menjaga Kerukunan Antar Umat Beragama di Aceh Tengah). Jurnal As-Salam (Online), 3(1), 48-60. http://jurnal-assalam.org/index.php/JAS/article/view/ 119

Rohmadi, Muhammad dan Yakun Nasucha. (2017). Dasar-dasar Penelitian Bahasa, Sastra, dan Pengajaran. Surakarta: Pustaka Briliant.

Sasangka, Sry Satriya Tjatur Wisnu. (2013). Gapura Bahasa Indonesia. Yogyakarta: Elmatera.

Sayska, Dwi Sukmanila dan Muhammad Arif. (2019). Menepis Argumen Pendukung LGBT dari Persfektif Hadis Nabawi. Jurnal As-Salam (Online), 3(1), 23-35. http://jurnal-assalam.org/index.php/JAS/article/view/117

Sultan. (2013). Penggunaan Kalimat dalam Artikel Ilmiah Hasil Penelitian. Jurnal penelitian Pendidikan Insani (Online), 14(1), 33-38. http://eprints.unm.ac.id/13024/

Suwandi, Sarwiji. (2010). Serbalinguistik (Mengupas Perlbagai Praktik Berbahasa). Surakarta: LPP UNS dan UNS Press.

Tussolekha, Rohmah. (2019). Kesalahan Penggunaan Ejaan Bahasa Indonesia pada Makalah Karya Mahasiswa. AKSARA: Jurnal Bahasa dan Sastra (Online), 20(1), 35-43.

http://jurnal.fkip.unila.ac.id/index.php/aksara/article/download/ 17810/12714

Umar, Ali dan Nurul Qomariyah Ahmad. (2019). Analisis Kemampuan Berpikir Kreatif Matematis Calon Guru Matematika. Jurnal As-Salam (Online), 3(1), 36-47. http://jurnal-assalam.org/index.php/JAS/article/view/118 